\title{
PROPERTIES OF LIGHTWEIGHT CONCRETE CONTAINING TREATED PUMICE BY ALKALINE SOLUTION
}

\author{
HESHAM ALSHARIE \\ Jerash University \\ Civil Engineering Department \\ P.O. Box 954 \\ Irbid -Jordan
}

\begin{abstract}
The properties of lightweight concrete containing pumice treated with sodium hypochlorite $(\mathrm{NaOCl})$, were experimentally investigated in this study. The study used treated pumice as $100 \%$ replacement of fine and coarse aggregates in concrete mixtures. Untreated pumice aggregates were used to prepare reference mixtures. In addition, the study investigated the effect of sodium hypochlorite on pumice proper-ties. The concrete compressive strength at ages of 7 and 28 days was tested. The results showed that the compressive strength of concrete that contained treated pumice increased by $200 \%$ as compared to concrete containing untreated pumice. The pumice aggregate treated with $\mathrm{NaOCl}$ increased the pumice strength and improved its physical characteristics as the mean of specific gravity and abrasion resistance.

Introduction. Lightweight concrete (LWC) is considered a suitable construction alternative whenever it is essential to reduce the dead-loads in structures, and saving energy conservations whenever there is an abundance of local lightweight aggregates [1]. However, for many purposes, the advantages of lightweight concrete outweigh its disad-vantages, and there is a continuing worldwide trend towards more light-weight concrete in applications such as pre-stressed concrete, high-rise buildings and even shell roofs. In general, lightweight concrete has a density ranged between 800 to $1800 \mathrm{~kg} / \mathrm{m}^{3}$ [2]. Using porous lightweight aggregates instead of traditional material can lower concrete density. Pumice is frequently used as a lightweight aggregate mainly for light-weight structural concretes. Pumice aggregate exists in several places around the world, where volcanoes have erupted [3]. Large number of re-searchers studied the properties of concrete containing pumice aggregate;
\end{abstract}


many of them conduce with admixtures such as Superplastizer and Slica fume to enhance properties of concrete. Limited number of researches considered that using treated pumice with sodium hypochlorite could improve lightweight concrete strength. Abdulla et al. [4] studied the effect of using treated rubber in the properties of lightweight cement mortar.

Kilıç et al. [5] studied the effect of aggregate on lightweight concretes (LWC) unit weight and strength characteristics. Five different light-weight concrete mixtures with five different aggregates were used to achieve study objective, pumice aggregate lightweight concrete (PLWC), a scoria aggregate lightweight concrete (SLWC), and three scoria-pumice commixture aggregate lightweight concretes (SPLWC-I, (SPLWC-II) and (SPLWC-III). Average dry unit weights of (PLWC), (SLWCSPLWC-I), (SPLWC-II) and (SPLWC-III) mixtures were 1368, 1696, 1638, 1477, $1997 \mathrm{~kg} / \mathrm{m}^{3}$, respectively. Specimen's compressive and flexural tensile strength and unit weight were determined at 28 days period. The result shows that the (PLWC), (SLWC), (SPLWC-I), (SPLWC-II), and (SPLWCIII) mixtures generated 15.8, 44.1, 30.5, 27.6, 23.3, MPa compressive strength, respectively. Uğur [6] studied the ability of improving the strength of the lightweight concretes containing pumice aggregate using several additional admixtures and mixes. The experimental investigation conducted on Turkish pumice lightweight concretes showed that different types of additives could increase the strength of pumice. The increase in fine aggregates obtained high strength; thus, it is not desired to use high quantities of line aggregates, because of the high density. Binici [7] studied the effect of using crushed ceramic and basaltic pumice as fine aggregates on concrete mortars properties. Results indicated that ceramic wastes and basaltic pumice concretes had good workability. It was found also that abrasion re-sistance has increased as the rate of fine crushed ceramic and crushed basaltic pumice increased. Fine crushed ceramic concrete had $30 \%$ low-er abrasion than crushed basaltic pumice concrete. The compressive strength of concrete increased with fine crushed ceramic content.

Finally, Results of this study showed that we can use fine crushed ceramic and crushed basaltic pumice very conveniently in concrete to achieve high abrasion resistance and high compressive strength. A.Abdulla [8] studied the properties of lightweight cement mortar using porcelain stone as fine aggregate. Porcelain stone as fine aggregate was used to produce lightweight cement mortar with good compressive 
strength. The porcelain stone was treated with Sodium Hypochlorite to improve the mechanical properties of this lightweight stone. The results show a significant improvement in the mechanical properties of cement mortar and a decrease in absorption of porcelain stone with small in-crease in density less than $8 \%$.

This paper presents the results of an experimental investigation on the effect of using treated pumice stone as fine and coarse aggregate on lightweight concrete properties. Treated pumice was used as $100 \%$ replacement of fine and coarse aggregate in concrete mixtures. Untreated pumice aggregate was used to prepare reference mixtures. This study also investigated the effect of sodium hypochlorite on pumice properties. The experimental program was conducted on $(150 \times 150 \times 150 \mathrm{~mm})$ cubes and $(150 \times 300 \mathrm{~mm})$ cylinders. Compressive strength was tested at an age of 7 and 28 days. Additionally $100 \times 100 \times 100 \mathrm{~mm}$ cubes of pumice stone were used to determine pumice stone compressive strength, specific gravity, unit weight, and abrasion resistance.

\section{Methodology}

Materials. Cement: Ordinary Portland cement (Type 1 produced by Lafarge Company) was used where it is confirmed by ASTM C-150 Type 1 [9].

Pumice: Pumice rocks used are from Al-Safawi region, east of Jordan. Pumice cubes were cut to cubes with approximately $100 \mathrm{~mm}$ cross sectional dimension. Pumice cubes were crushed in to different sizes to be used as fine and coarse aggregate (maximum size $20 \mathrm{~mm}$ ) which were used to prepare control and treated concrete specimens. Table 1 shows the characteristics of pumice stone. Table 2 shows the sieve analysis, test results for pumice aggregate.

Table 1

Characteristics of pumice aggregate before and after treatment

\begin{tabular}{|l|c|c|c|c|}
\hline \multicolumn{1}{|c|}{$\begin{array}{c}\text { Physical } \\
\text { Properties }\end{array}$} & $\begin{array}{c}\text { Untreated } \\
\text { Pumice } \\
\text { As fine } \\
\text { aggregate }\end{array}$ & $\begin{array}{c}\text { Untreated } \\
\text { Pumice } \\
\text { As coarse } \\
\text { aggregate }\end{array}$ & $\begin{array}{c}\text { Treated } \\
\text { Pumice } \\
\text { As fine } \\
\text { aggregate }\end{array}$ & $\begin{array}{c}\text { Treated } \\
\text { Pumice } \\
\text { As coarse } \\
\text { aggregate }\end{array}$ \\
\hline Color & 2 & 3 & 4 & 5 \\
\hline $\begin{array}{l}\text { Compressive } \\
\text { strength (MPa) }\end{array}$ & Dark grey & Dark grey & Black & Black \\
\hline
\end{tabular}


Окончание табл. 1

\begin{tabular}{|l|c|c|c|c|}
\hline \multicolumn{1}{|c|}{1} & 2 & 3 & 4 & 5 \\
\hline Density kg/m & \multicolumn{2}{|c|}{1096.5} & \multicolumn{2}{c|}{1174.5} \\
\hline Specific gravity & 1.66 & 1.8 & 1.7 & 1.88 \\
\hline Absorption & $8 \%$ & $6.6 \%$ & $6 \%$ & $3.4 \%$ \\
\hline Abrasion & - & $55 \%$ & - & $45 \%$ \\
\hline
\end{tabular}

Table 2

Sieve analysis test results for pumice

\begin{tabular}{|l|c|}
\hline Sieve size & $\begin{array}{c}\text { Passing percent \% for pumice } \\
\text { Aggregate }\end{array}$ \\
\hline $10.00 \mathrm{~mm}$ & 97 \\
\hline $5.00 \mathrm{~mm}$ & 93 \\
\hline $2.36 \mathrm{~mm}$ & 77 \\
\hline $1.18 \mathrm{~mm}$ & 40 \\
\hline $600 \mu \mathrm{m}$ & 33 \\
\hline $300 \mu \mathrm{m}$ & 15 \\
\hline $150 \mu \mathrm{m}$ & 11 \\
\hline
\end{tabular}

Alkaline solution: Sodium hypochlorite $(\mathrm{NaOCl}) 0.1 \mathrm{M}, \mathrm{pH}=$ 12 was used to treat pumice stone.

Treatment and mixing. Treatment: A total of six pumice cubes were immersed in $\mathrm{NaOCl}$ alkaline solution for 24 hours then washed very well and dried in oven to remove the effect of alkaline solution on concrete, after that the compressive strength were tested. Table 1 shows characteristics of treated pumice as fine and coarse aggregate. Specific gravity and absorption for fine and coarse aggregate were obtained according to (ASTMC128-88) and (C127-88) [10-11]. Sieve analysis and abrasion were conducted according to (ASTM C136-84a) and (C13188) [12-13]. Figure shows pumice cubes after treatment. 

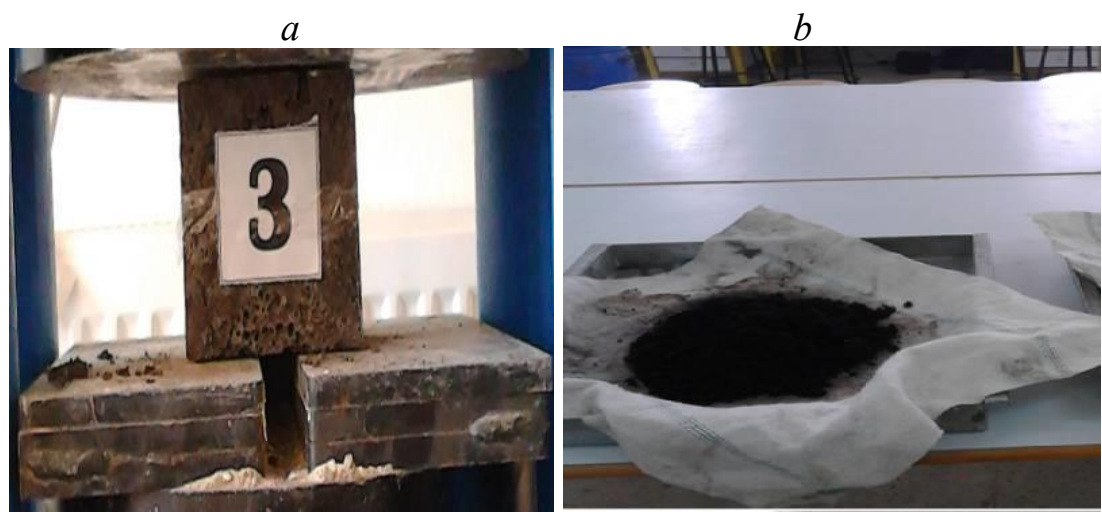

Fig. 1. Treated pumice cubes $(a)$ before crushing $(b)$ after crushing Mixing

All concrete mixtures were of the same proportions of concrete ingredients. The proportions of the cement content, water content, and pumice as fine and coarse aggregate were $336 \mathrm{~kg} / \mathrm{m}^{3}, 246 \mathrm{~kg} / \mathrm{m}^{3}, 519 \mathrm{~kg} / \mathrm{m}^{3}$ and 415 $\mathrm{kg} / \mathrm{m}^{3}$, respectively. The maximum aggregate size was $20 \mathrm{~mm}$. The proportions were determined according ACI-211mix design procedure and a. A. M. Neville and J. J. Brooks design of light-weight aggregate [14-15] to achieve a $20 \mathrm{MPa}$ compressive strength and $9.5 \mathrm{~cm}$ slump. Slump test obtained was according to ASTM C143 [16]. Casting and curing of concrete cylinders and cubes were done according to ASTM C 39-86[17].

\section{Results and discussions:}

Color

Pumice cubes color changed from dark grey to black after treating by $\mathrm{NaOCl}$.

Density

Pumice cubes density increased about $7 \%$ by $\mathrm{NaOCl}$ solutions, as shown in Table 3 and Table 4.

Specific gravity

$\mathrm{NaOCl}$ solution caused slight increase in the pumice specific gravity. Specific gravity of treated pumice used as fine aggregate is approximate-ly $2.4 \%$ higher than untreated pumice, whereas specific gravity of treat-ed pumice used as coarse aggregate is approximately $2 \%$ higher than untreated pumice as shown in Table 1. 
Absorption

Results showed that $\mathrm{NaOCl}$ solution decreased absorption percentage about $25 \%$ and $48 \%$ for fine and coarse pumice aggregate, respectively as shown in Table 1.

Table 3

Compressive strength of untreated pumice cubes

\begin{tabular}{|l|c|c|c|c|c|}
\hline $\begin{array}{c}\text { Cube } \\
\#\end{array}$ & $\begin{array}{c}\text { Cube } \\
\text { cross } \\
\text { sectional } \\
\text { area } \\
\left(\mathrm{mm}^{2}\right)\end{array}$ & $\begin{array}{c}\text { Sample } \\
\text { volume } \\
\left(\mathrm{mm}^{3}\right)\end{array}$ & $\begin{array}{c}\text { Sample } \\
\text { weight } \\
(\mathrm{g})\end{array}$ & $\begin{array}{c}\text { Sample } \\
\text { density } \\
\left(\mathrm{kg} / \mathrm{m}^{3}\right)\end{array}$ & $\begin{array}{c}\text { Compressive } \\
\text { strength } \\
\left(\mathrm{N} / \mathrm{mm}^{2}\right)\end{array}$ \\
\hline 1 & 96303 & 956697 & 1103 & 1152 & 21.8 \\
\hline 2 & 10506 & 1071612 & 1198 & 1118 & 20.1 \\
\hline 3 & 10100 & 99990 & 1075 & 1075 & 20.2 \\
\hline 4 & 9120 & 866400 & 1032 & 1191 & 19.2 \\
\hline 5 & 10815 & 1146390 & 1141 & 995 & 20.2 \\
\hline 6 & 11128 & 1179568 & 1236 & 1048 & 15.2 \\
\hline Sum & 147972 & 5320657 & 6785 & 6579 & 116.6 \\
\hline Av. & 33273.5 & 1614103 & 2077.8 & 2001 & 35.2 \\
\hline
\end{tabular}

Abrasion

$\mathrm{NaOCl}$ solution increased pumice abrasion resistance. $\mathrm{NaOCl}$ solution decreased pumice abrasion ratio about $3.85 \%$ as shown in Table 1.

Compressive strength of limestone and pumice cubes

Table 2 shows the results of untreated pumice cubes compressive strength. The results indicated that the average compressive strength of untreated pumice cubes is equal to $19.4 \mathrm{MPa}$. Table 3 shows that treated pumice cubes have an average compressive strength equal to $30.49, \mathrm{MPa}$. $\mathrm{NaOCl}$ solution increased strength of pumice cubs about $36 \%$ as compared with untreated pumice cubes. Fig. 2 shows the compressive strength of treated pumice. 
Compressive strength of concrete cubes and cylinders

Table 5 shows that the compressive strength of concrete containing treated pumice cubes at 7 and 28 ages increased about $208 \%$ and $203 \%$, respectively as compared with concrete containing untreated pumice aggregate. Table 6 shows that the average compressive strength of treated pumice concrete cylinders increased about $189 \%$ and $209 \%$ at ages of 7 and 28 days, respectively. Figures 2 and 3 summarize the results graphically. Figure 4 shows the compressive strength of treated pumice concrete cubes and cylinders.

The results show the high effect of a very inexpensive alkaline solution on the increase of concrete strength.

Table 4

Compressive strength of treated pumice cubes

\begin{tabular}{|l|c|c|c|c|c|}
\hline $\begin{array}{c}\text { Cube } \\
\#\end{array}$ & $\begin{array}{c}\text { Cube } \\
\text { cross } \\
\text { sectional } \\
\text { area } \\
\left(\mathrm{mm}^{2}\right)\end{array}$ & $\begin{array}{c}\text { Sample } \\
\text { volume } \\
\left(\mathrm{mm}^{3}\right)\end{array}$ & $\begin{array}{c}\text { Sample } \\
\text { weight } \\
(\mathrm{g})\end{array}$ & $\begin{array}{c}\text { Sample } \\
\text { density } \\
\left(\mathrm{kg} / \mathrm{m}^{3}\right)\end{array}$ & $\begin{array}{c}\text { Compressive } \\
\text { strength } \\
\left(\mathrm{N} / \mathrm{mm}^{2}\right)\end{array}$ \\
\hline 1 & 8648 & 769672 & 1013 & 1310 & 26.5 \\
\hline 2 & 9408 & 921984 & 1075 & 1166 & 27.3 \\
\hline 3 & 11448 & 119592 & 1136 & 954 & 36.1 \\
\hline 4 & 10710 & 1145970 & 1162 & 1014 & 35.3 \\
\hline 5 & 8930 & 866210 & 1126 & 1230 & 28.6 \\
\hline 6 & 8740 & 795522 & 1092 & 1373 & 29.2 \\
\hline Sum & 57884 & 4618950 & 6604 & 7047 & 182.9 \\
\hline Av. & 17853.3 & 1411371 & 2032.5 & 2130.7 & 56.6 \\
\hline
\end{tabular}

Table 5

Average compressive strength of concrete cubes with untreated pumice and treated pumice

\begin{tabular}{|l|c|c|c|c|}
\hline & $\begin{array}{c}\text { Age } \\
\text { (days) }\end{array}$ & $\begin{array}{c}\text { Untreated } \\
\text { Pumice } \\
(\mathrm{MPa})\end{array}$ & $\begin{array}{c}\text { Treated } \\
\text { Pumice } \\
(\mathrm{MPa})\end{array}$ & $\begin{array}{c}\text { Increment } \\
\text { Percent }(\%)\end{array}$ \\
\hline \multirow{2}{*}{ Mixture 1 } & 7 & 14.2 & 30.7 & $216 \%$ \\
\cline { 2 - 5 } & 28 & 23.2 & 46.2 & $208 \%$ \\
\hline \multirow{2}{*}{ Mixture 2 } & 7 & 15.5 & 32.3 & $200 \%$ \\
\cline { 2 - 5 } & 28 & 23.8 & 47.2 & $198 \%$ \\
\hline
\end{tabular}


Table 6

Average compressive strength of concrete cylinders with untreated pumice and treated pumice

\begin{tabular}{|c|c|c|c|c|}
\hline & $\begin{array}{c}\text { Age } \\
\text { (days) }\end{array}$ & $\begin{array}{c}\text { Untreated } \\
\text { Pumice } \\
(\mathrm{MPa})\end{array}$ & $\begin{array}{c}\text { Treated } \\
\text { Pumice } \\
(\mathrm{MPa})\end{array}$ & $\begin{array}{c}\text { Increment } \\
\text { Percent }(\%)\end{array}$ \\
\hline \multirow{2}{*}{ Mixture 1 } & 7 & 14.2 & 26.9 & $189 \%$ \\
\cline { 2 - 5 } & 28 & 21.2 & 44.5 & $209 \%$ \\
\hline
\end{tabular}

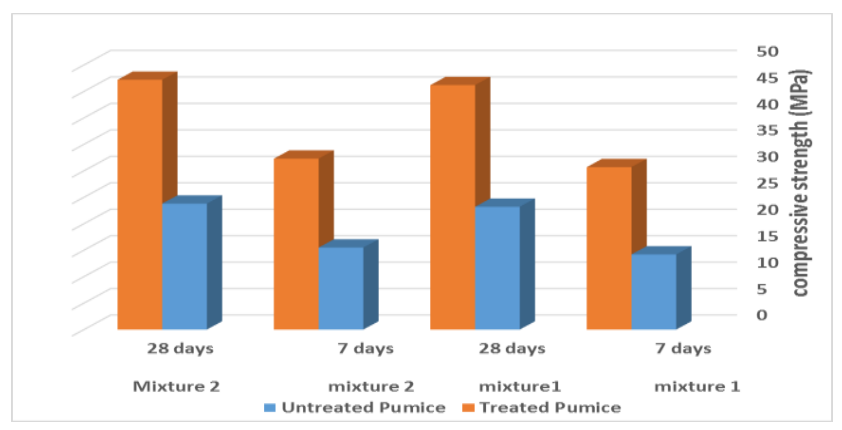

Fig. 2. Average compressive strength of concrete cubes with untreated pumice and treated pumice

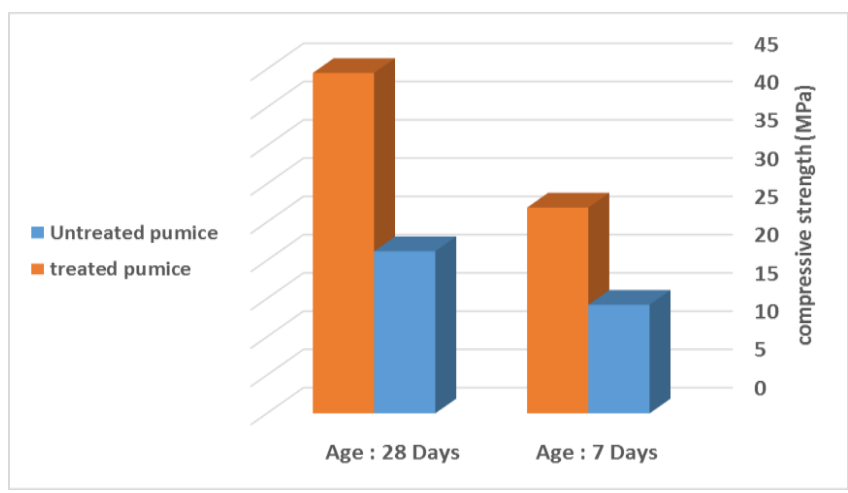

Fig. 3. Average compressive strength of concrete cylinders with untreated pumice and treated pumice 


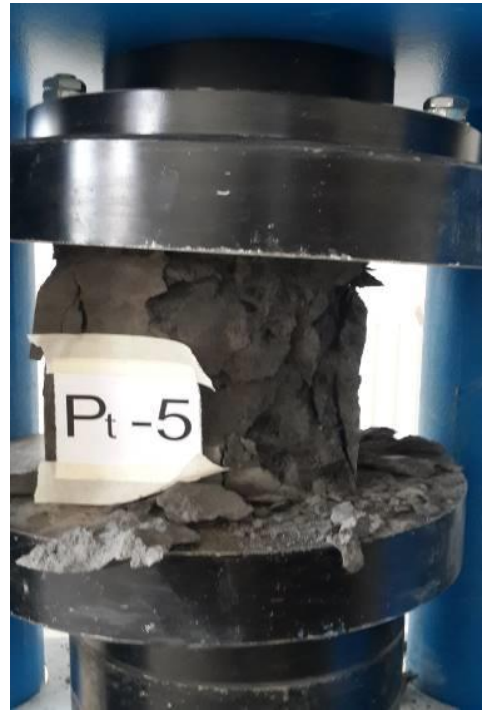

$a$

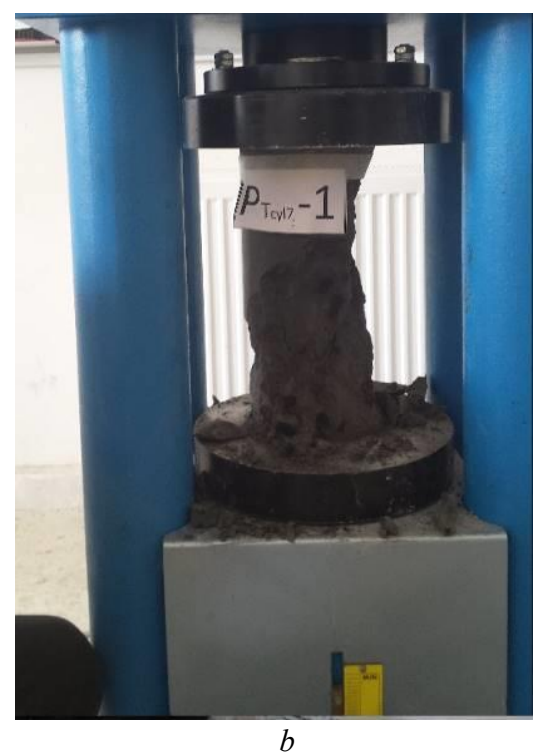

b

Fig. 4. Compressive strength testing of ( $a$ ) Treated pumice concrete cubes $(b)$ Treated pumice concrete cylinders

Conclusion. $\mathrm{NaOCl}$ solution improves pumice properties and thus the properties of concrete that contain treated pumice are improved. The following remarks can be summarized as per to the experimental study. It showed that the $\mathrm{NaOCl}$ increased pumice density and specific gravity about $7 \%$ and $2.4 \%$, respectively. $\mathrm{NaOCl}$ also affected pumice abrasion resistance since the abrasion percentage decreased about $3.85 \%$. With that said, $\mathrm{NaOCl}$ adversely affects pumice absorption and in-creases pumice compressive strength by app. $36 \%$ as compared to un-treated pumice aggregate. Using treated pumice increases concrete compressive strength more than ten times compared to its original strength. Finally, Using treated pumice is recommended to produce lightweight concrete with high strength.

Recommendation for future works. Make an SEM (Scanning electronic microscope) tests on concrete that contains pumice treated with $\mathrm{NaOCl}$ solution and several physicochemical tests on pumice treated with $\mathrm{NaOCl}$. 
Acknowledgement. The author would like to thank Prof. Aziz I. Abdulla for his guidance, valuable recommendations and endless help throughout this research.

\section{REFERENCES}

1. E. Yeoh, H. Koh, F. Zamzuri Flexural strength of timberlightweight concrete composite beam. Brunei international Conference on Engineering and Technology 20Q5 (BICET 2005), 15-17 August 2005, Brunei.

2. A.Kan, R. Demirboga.A novel material for lightweight concrete production Cement and concrete composites2009; 31(7):489-495.

3. A. Kornev, G. Kramar, A. Kudryavlsev. 1980. Design peculiarities of-pre-stressed supporting constructions from concretes on porous aggregates. The Com rete Society, The Constitution Press. Lancester. London, New York.UK.

4. Abdulla, Aziz Ibrahim, Wisam Amer Aules, and Salwa Hadi Ahmed. Cement Mortar Properties Contain Crumb Rubber Treated with Alkaline Materials, Modern Applied Science 4.12 (2010): p156.

5. C. Kilic1, Ati. D, A. Teymen, O. Karahan, A.Kamuran. The effects of scoria and pumice aggregates on the strengths and unit weights of lightweight concrete scientific Research and Essay 2009; 4(10): 9619656. İ.Uğur, "Improving the strength characteristics of the pumice aggregate lightweight concretes." 18th International Mining Congress and Exhibition at Turkey-IMCET 2003, 2003, ISBN 975-395-605.

7. H. Binici. Effect of crushed ceramic and basaltic pumice as fine aggregates on concrete mortars properties. Construction and Building Materials 2007. 21 (2007): 1191-1197.

8. A. Abdulla, H. Saleh, Y. Salih. Lightweight cement mortar using treated porcelain. International Review of Civil Engineering 2012; 3(1).

9. ASTM C-150: Standard Specification for Portland cement.

10. ASTM C128-88: Standard test method for specific gravity and absorption of fine aggregate.

11. ASTM C 127-88: Standard test method for specific gravity and absorption of coarse aggregate.

12. ASTM C136-84a: Standard test method for sieve analysis of fine and coarse aggregate).

13. ASTM C 131-88: Standard test method for abrasion (Los Angeles machine). 
14. American Concrete Institute. (1991). "Standard practice for selecting properties for normal, heavyweight and mass concrete". ACI committee 211.1, Farmington Hills, USA.

15. A.M Neville and J. J. Brooks, Concrete technology. Philadelphia, 2010, design of light weight aggregate mixes pp: 392-393.

16. Standard test method for test for compressive strength of cylindrical concrete specimens: ASTM C 39-86.

17. Standard test method for slump of hydraulic-cement concrete: ASTM C143. 